an objective remission in one patient who underwent hormonal ablation and was shown to be ER-negative, PgR-positive.

I hope that the above-cited references will correct the impression that only ER-positive tumours contain $\mathrm{PgR}$. Although the number of cases of PgR-positive, ER-negative tumours is small, they do exist. The importance of recognising this group of mammary carcinomas is that it may provide new insights into the interrelationship that exists between various hormones, their receptors, and tumour regression.

JEROME APPELBAUM

Department of Medicine,

Maimonides Medical Center,

Brooklyn, New York

Raynaud, J P, fournal of Steroid Biochemistry, 1975 14, 6. 37,464

Tobin, E H, et al, in Multiple Molecular Forms of Steroid Hormone Receptors, ed M K Agarwal, p 181 Amsterdam, Elsevier/North-Holland Biomedical

McGuire, W L, Horowitz, K B, and DeLaGarza, M in Cancer: Trends in Research and Treatment, ed C Heuson, W $H$ Mattheim, and $M$ Rozencweig, p 181. New York, Raven Press, 1976.

Degenshein, G A, et al, Breast, 1977, 3, 29.

Horowitz, K B and McGuire, W L, in Progesterone Receptors in Normal and Neoplastic Tissue, ed W I McGuire, J P Raynaud, and E E Baulieu, p 102 New York, Raven Press, 1977

King, R J B, First Innsbruck Winter Conference on Biochemistry in Clinical Medicine, Innsbruck, Austria, January 1978

Bloom, N, Tobin, E H, and Degenshein, G A, in Progesterone Receptors in Normal and Neoplastic Tissue, ed W L McGuire, J P Raynaud, and

**We would agree that the statement that progesterone receptors occur only in patients who are ER-positive is too absolute. As $\mathrm{Dr}$ Appelbaum points out, PgR have been reported in a few ER-negative patients, though it is of interest that there is a clear relationship between the concentrations of oestrogen and progesterone receptors even in those patients who are reported as receptorpositive. ${ }^{1-3}$ Clinical studies of hormone responsiveness in this small group of patients will be required before the meaning and relevance of such a finding are evident.-ED, BMf.

${ }^{1}$ Pichon, M F, and Milgram, E, Cancer Research, 1977, 37, 464

Horowitz, K B, and McGuire, W L, in Progesteron Receptors in Normal and Neoplastic Tissue, ed W L McGuire, J P Raynaud, and E E Baulieu, p 102 New York, Raven Press, 1977.

Leclercq, G, et al, in Progesterone Receptors in Normal and Neoplastic Tissue, ed W L McGuire, J P Raven Press, 1977.

\section{Thyroid function tests}

SIR, - We read with interest the comments of Mr M G Davies and Dr $H$ Allison and of Dr W A Burr (9 September, p 771) on our paper on thyroid function tests in patients with abnormal concentrations of thyroxinebinding proteins (12 August, $\mathrm{p} 477$ ).

We agree with Mr Davies and Dr Allison that the free thyroxine index (FTI), whether modified as we suggested or not, may be misleading in patients with very high concentrations of thyroxine-binding globulin (TBG) because of the limitations of the Thyopac-3 technique. ${ }^{1}$ To check whether erroneous high values influenced the normal range for our modification of the FTI we recalculated it using data from only those patients with Thyopac- 3 values of $120 \%$ or less. The $95 \%$ limits obtained using the data did not differ from those for all 200 patients. Thus our reference range remains valid. Their suggestion that a single zero standard will resolve the "zero error" in the conventional FTI is incorrect because of the spread of values at very low thyroxine (T4) and Thyopac- 3 values.

We suggested in our paper that further investigation is needed to determine whether the T4:TBG ratio or our modification of the FTI provides the better discriminant for the evaluation of thyroid function in patients with abnormal binding proteins. The original paper by Dr Burr and his colleagues ${ }^{1}$ gave data on patients with absent TBG but none on euthyroid patients with such conditions as nephrotic syndrome or chronic liver disease who have measurable TBG values below $5 \mathrm{mg} / \mathrm{l}$. In his letter Dr Burr gives the numbers of false-negative diagnoses for our modification of the FTI, the conventional FTI, and the T4:TBG ratio in 101 patients with thyrotoxicosis and 36 with myxoedema. He concludes that the modified FTI is "almost certainly inferior" to the T4:TBG ratio. However, the diagnostic efficiency of a test depends not only on the false-negative rate but also on the false-positive rate, and both are needed, particularly in patients with abnormal binding proteins, before conclusions can be drawn.

The first-line tests of thyroid function are commonly estimations of either total T4 and thyroid-stimulating hormone or total $\mathrm{T} 4$ and triiodothyronine, depending on the clinical situation. It may well be that in those patients in whom measurement of binding proteins is indicated the T4:TBG ratio will provide a better discriminant than our modification of the FTI. However, we believe that this remains to be proved.

P SHERIDAN

R B PAYNE

St James's University Hospital

${ }^{1}$ Burr, W A, et al, British Medical fournal, 1977, 1, 485.

Postpartum haemorrhage after induced and spontaneous labour

SIR,-Surgeon Commander P R S Brinsden and Mr A D Clark (23 September, p 855) may be interested in the results of an analysis I made into the relationship between the administration of oxytocics during labour and primary postpartum haemorrhage at this hospital during 1974.

Of the 907 deliveries occurring during that year, $49 \cdot 2^{\circ}$ o were induced and $54.1 \%$ were preceded by administration of an oxytocic to

Oxytocic administration and postpartum haemorrhage (No of cases)

\begin{tabular}{|c|c|c|c|c|c|c|}
\hline & \multicolumn{2}{|c|}{$\begin{array}{c}\text { Syntocinon } \\
\text { infusion }\end{array}$} & \multirow{2}{*}{$\begin{array}{c}\text { Buccal } \\
\text { oxytocin }\end{array}$} & \multirow{2}{*}{$\begin{array}{c}\text { Dinoprostone } \\
\text { oral } \\
\text { solution }\end{array}$} & \multicolumn{2}{|c|}{ No oxytocic } \\
\hline & $\begin{array}{l}\text { Primi- } \\
\text { gravidae }\end{array}$ & $\begin{array}{c}\text { Multi- } \\
\text { gravidae }\end{array}$ & & & $\begin{array}{c}\text { Primi- } \\
\text { gravidae }\end{array}$ & $\begin{array}{c}\text { Multi- } \\
\text { gravidae }\end{array}$ \\
\hline Total treated $\ldots$ & 164 & 143 & 130 & 54 & 144 & 272 \\
\hline $\begin{array}{l}\text { Simple postpartum } \\
\text { haemorrhage }\end{array}$ & 4 & 8 & 1 & 1 & 3 & 5 \\
\hline $\begin{array}{l}\text { Postpartum } \\
\text { haemorrhage and }\end{array}$ & & & & & & \\
\hline $\begin{array}{l}\text { forceps delivery } \\
\text { Postpartum }\end{array}$ & 3 & - & - & - & 4 & - \\
\hline $\begin{array}{l}\text { haemorrhage and } \\
\text { manual removal of }\end{array}$ & & & & & & \\
\hline$\underset{\text { potal postpartum }}{\text { placenta }} \ldots$ & 1 & 1 & 2 & - & - & 1 \\
\hline haemorrhage & 8 & $9^{*}$ & 3 & 1 & 7 & $6^{*}$ \\
\hline
\end{tabular}

$* \chi^{2}=3 \cdot 4: P<0 \cdot 10$ induce or accelerate labour. The incidence of primary postpartum haemorrhage, defined as a loss of $500 \mathrm{ml}$ or more within $24 \mathrm{~h}$ of delivery,

No relationship was apparent between oxytocin infusion and primary postpartum haemorrhage in primigravidae. In multigravidae, however, the relationship may have been clinically significant. The oxytocin regimen used was that described by Normington. ${ }^{1}$

Sheppey General Hospital,

Minster-on-Sea,

' Normington, E A M, fournal of Obstetrics and Gynaecology of the British Commonwealth, 1972,

SIR,-I am grateful for the study by Mr P R S Brinsden and Mr A D Clark (23 September, p 855) of the impact of induction of labour on the incidence of postpartum haemorrhage. Indeed, postpartum haemorrhage may be, and too often is, a complication of induced labour. However, one very simple measure-the continuation of the intravenous oxytocic infusion for, say, one hour after the delivery of the of labour coined by our USA colleagues) is supreme for the prevention of this complication. That hypotonic postpartum haemorrhage is indeed preventable has been clearly shown by our analysis of a consecutive series of about 1700 elective labour inductions by means of low amniotomy and intravenous oxytocin, prostaglandin $\mathrm{E}_{21}$ or prostaglandin $\mathrm{F}_{2} \alpha$.

\section{Michel Thiery}

Department of Obstetrics,

Academic Hospital,

Ghent,

\section{Radiology work load}

SIR,-The extraordinary response from Dr M Lea Thomas (2 September, p 706) to my paper on radiology work load (12 August, $\mathrm{p}$ 514) has deflected the debate from the central issue.

My objective is a system of radiological practice in which patients derive maximum benefit. My thesis is that each department has a capacity limited by the need to maintain reasonable professional standards. Where demand exceeds this reasonable capacity priorities are determined by consultation with users. Urgent work is done before less urgent, which may have to wait. The length of this wait will diminish if inappropriate requests are not initiated. Although this was as shown in the table below. placenta (the duration of the "fourth stage" 